\title{
Impact of Value Addition Training Programmes of KVK in Kolar District, Karnataka
}

\author{
Jayalaxmi Pawar* , A. M. Rajesh, P. Pushpa, G. S. Chikkanna, \\ K. Tulasiram and D. S. Ambika \\ Agril.Extension, College of Horticulture, Kolar, India \\ *Corresponding author
}

Keywords

KVK, Value addition, SHGs

Article Info

Accepted:

12 November 2020 Available Online:

10 December 2020

\begin{abstract}
A B S T R A C T
Value addition in agriculture and horticulture has increased the opportunities for employment, financial stability and opportunities for small farms and enterprises. Therefore the present study is carried out to know the impact of value addition training programmes on farm families. The study explored, to what extent the training programme of value addition had been changing participants' perceived knowledge, acquisition of skills and adoption level. Likert-type scales were used to assess the knowledge gained, skills acquired and some of the case studies are reported. The findings of the study concluded that value addition training of KVK have brought a considerable positive impact on the beneficiaries in terms of perceived knowledge, skills acquired and adoption level. Therefore this study may be helpful in developing or planning future value added training programme in such a way that is conducive to farm women, SHGs. To increase the level of adoption, beneficiaries needs to be provided credit with a minimum interest rate and generating market at the root level by the government and number of follow up activities should be carried out.
\end{abstract}

\section{Introduction}

Value addition in agriculture and horticulture has increased the opportunities for employment, financial stability and opportunities for small farms and enterprises. Value addition in agriculture and allied sectors offers an opportunity to increase and stabilize farm income. It is estimated that the post harvest losses of fruits and vegetables amounts to about $40 \%$ of total annual production in India. Therefore, value addition training programmes are carried out through
KVK. Training is considered as part of strategy for growth and development of an organization and important aspect of the entrepreneurship development. Basically training is intended to help individuals to learn and to bring a desired standard of efficiency, condition and behaviour. The major objectives of $\mathrm{KVK}$ is to organize need based and skill oriented training programmes for practicing farmers and farm women by the principles of 'Learning by doing' and 'Teaching by doing'. The farmers, farm women and rural youth in the Kolar District 
are being benefited through Trainings and Extension activities.

Krishi Vigyan Kendra (KVK) is a district level resource and knowledge centre to cater the needs of the farming community of Kolar district established by ICAR, New Delhi in the year 2012.This KVK comes under the jurisdiction of University of Horticultural Sciences, Bagalkot. Krishi Vigyan Kendra (KVK) was to cater the needs of the farming community of Kolar district. Finger millet, maize, groundnut and pulses are the predominant crops of farmers at Kolar. Cultivable lands are mainly rainfed and dry farming is a characteristic feature of the district. The important irrigated crops are paddy, mulberry, sugarcane, potato and other vegetables. Horticulture is considered to be one of the primary occupations for this district. Tomato and mango are the main horticultural crops and this study also given importance on the training programmes of value addition of horticultural crops.

Therefore it's necessary to study the impact of value addition training programmes on farm families with the following to assess perceived knowledge of beneficiaries before and after value addition training programmes.

To study the skills acquired by trainees before and after value addition training programmes. To find out the adoption level of participants of value addition training programmes.

\section{Materials and Methods}

The study was conducted in Kolar District of Karnataka state, India in the year 2017-18 and 2018-19. This district was purposively selected as the KVK beneficiaries belong to this district of different talukas.
Purposively selected sample of 70 beneficiaries of value added training programmes of horticultural crops. The Interview Schedule was developed on the review of the value addition training and other contents. The data were collected with the help of interview schedule. Therefore face to face interviews were carried out. For assessment of perceived knowledge \& skills acquisition, a scale ranging from 1-5 (VK, MK, SwK, NK, NaaK) was used. Similarly for adoption level after training was assessed using likert scale ranging from 1-3 (adopted, partially adopted and have not tried). A knowledge test was used (Pandey et al.,) to ascertain the knowledge and skills of the women on food processing practices before and after value addition training programmes of KVK.

\section{Results and Discussion}

It is clear from the Table 1 that value addition trainings organised at KVK consisted mainly of women trainees $(85.71 \%)$. About $54.28 \%$ of them were farm labourers. Forty two percent of the women participants were members of SHG for more than five years. The table 2 (a) indicates pre training knowledge of respondents which clearly states three fourth of the participants (75.71\%) had low level knowledge about value addition. Whereas Table 2 (b) post training knowledge of participants was high about $67.14 \%$. The data presented in Table 3(a) states that about $71.43 \%$ of the respondents were having low level of skills of value addition before training programme. After training there was increase in their skills level as they acquired through training is about $54.28 \%$ followed by $45.71 \%$ of medium level skills as shown in Table 3(b). 
Table.1 Demographic Profile of the Beneficiaries N=70

\begin{tabular}{|c|c|c|c|c|}
\hline S.No & $\begin{array}{l}\text { Demographic } \\
\text { profile }\end{array}$ & & Frequency & Percentage \\
\hline \multirow[t]{2}{*}{1.} & \multirow{2}{*}{ Gender } & Male & 10 & 14.28 \\
\hline & & Female & 60 & 85.71 \\
\hline \multirow[t]{5}{*}{2.} & \multirow[t]{5}{*}{ Education } & Up to Primary School(1-4) & 37 & 52.85 \\
\hline & & Middle School(5-7) & 20 & 28.57 \\
\hline & & High School (8-10) & 10 & 14.28 \\
\hline & & PUC (11-12) & 03 & 4.28 \\
\hline & & Graduate (above 12) & 00 & ---- \\
\hline \multirow[t]{4}{*}{3.} & \multirow[t]{4}{*}{ Family Income } & Large Farmers & 02 & 2.85 \\
\hline & & Medium Farmers & 15 & 21.42 \\
\hline & & Small Farmers & 15 & 21.42 \\
\hline & & Labours & 38 & 54.28 \\
\hline \multirow[t]{3}{*}{4.} & \multirow{3}{*}{$\begin{array}{l}\text { Extension } \\
\text { Contact }\end{array}$} & No frequent Extension contact & 35 & 50.00 \\
\hline & & $\begin{array}{l}\text { Extension contact (1-2 times) } \\
\text { month }\end{array}$ & 20 & 28.57 \\
\hline & & $\begin{array}{l}\text { Extension contact (>2 times) } \\
\text { month }\end{array}$ & 15 & 21.42 \\
\hline \multirow[t]{3}{*}{5.} & \multirow{3}{*}{$\begin{array}{l}\text { Membership of } \\
\text { SHGs }\end{array}$} & $<3$ years & 15 & 21.42 \\
\hline & & $3-5$ years & 25 & 35.71 \\
\hline & & $>5$ years & 30 & 42.85 \\
\hline
\end{tabular}

Table.2 (a) Pre-training knowledge score of participants

\begin{tabular}{|l|c|c|}
\hline Knowledge Level & No. of respondents (N=70) & Percentage \\
\hline Low level (0\% to 30\%) & 53 & $\mathbf{7 5 . 7 1}$ \\
\hline Medium level (30\% to 60\%) & 17 & 24.29 \\
\hline High level (60\% and above) & 00 & 00 \\
\hline
\end{tabular}

Table.2 (b) Post-training knowledge score of participants

\begin{tabular}{|l|c|c|}
\hline Knowledge Level & No. of respondents (N=70) & Percentage \\
\hline Low level $(\mathbf{0 \%}$ to 30\%) & 00 & 00 \\
\hline Medium level (30\% to 60\%) & 23 & 32.86 \\
\hline High level (60\% and above) & 47 & $\mathbf{6 7 . 1 4}$ \\
\hline
\end{tabular}

Table.3 (a) Pre-training value addition skills score of participants

\begin{tabular}{|l|c|c|}
\hline Skills Level & No. of respondents $(\mathrm{N}=70)$ & Percentage \\
\hline Low level $(\mathbf{0 \%}$ to 30\%) & 50 & $\mathbf{7 1 . 4 3}$ \\
\hline Medium level (30\% to 60\%) & 20 & 28.57 \\
\hline High level (60\% and above) & 00 & 00 \\
\hline
\end{tabular}


Table.3 (b) Post-training value addition skills score of participants

\begin{tabular}{|l|c|c|}
\hline Skills Level & No. of respondents $(\mathrm{N}=70)$ & Percentage \\
\hline Low level (0\% to 30\%) & 00 & 00 \\
\hline Medium level (30\% to 60\%) & 32 & 45.71 \\
\hline High level (60\% and above) & 38 & $\mathbf{5 4 . 2 8}$ \\
\hline
\end{tabular}

Table.4 (a) Distribution of participants based on adoption of perceived knowledge on value addition after training

\begin{tabular}{|l|c|c|c|c|c|}
\hline Statements & VK & MK & SwK & NK & NaK \\
\hline Value added Tomato food items like sauce, ketch up & $\mathbf{4 0}(\mathbf{5 7 . 1 4})$ & $14(20.00)$ & $15(21.42)$ & $01(1.42)$ & --- \\
\hline $\begin{array}{l}\text { Value added Ragi food items like laddu, Chakkali, } \\
\text { malt }\end{array}$ & $14(\mathbf{2 0 . 0 0 )}$ & $\mathbf{3 9}(\mathbf{5 5 . 7 1})$ & $15(21.42)$ & $02(2.85)$ & ---- \\
\hline Value added Jackfruit food items like jam, juice & $19(27.14)$ & $28(40.00)$ & $19(27.14)$ & $03(4.28)$ & $01(1.42)$ \\
\hline Value added Potato food items like chips & $20(28.57)$ & $38(54.28)$ & $07(10.00)$ & $04(5.71)$ & $01(1.42)$ \\
\hline Value addition of other minor millets & $07(10.00)$ & $35(50.00)$ & $26(37.14)$ & $2(2.85)$ & ---- \\
\hline Value addition of other mango like candies, jam & $15(21.42)$ & $\mathbf{3 7}(\mathbf{5 2 . 8 5})$ & $16(22.85)$ & $02(2.85)$ & --- \\
\hline Value added Amla food items like candies & $05(7.14)$ & $25(35.71)$ & $36(51.42)$ & --- & $04(5.71)$ \\
\hline Importance of packaging of value added products & $10(14.28)$ & $38(54.28)$ & $08(11.42)$ & $09(12.85)$ & $05(7.14)$ \\
\hline $\begin{array}{l}\text { Knowledge about economics of production costs } \\
\text { involve in alue added products }\end{array}$ & $08(11.42)$ & $30(42.85)$ & $23(32.85)$ & $05(7.14)$ & $04(5.71)$ \\
\hline Income generating activities of value added products & $07(10.00)$ & $24(34.28)$ & $33(47.14)$ & $03(4.28)$ & $02(2.85)$ \\
\hline
\end{tabular}

VK - Very Knowledgeable, MK- Moderately Knowledgeable, SwK -Some what Knowledgeable, NaaK- Not at all Knowledgeable

Table.4 (b) Distribution of participants based on adoption of skills on value addition after training

\begin{tabular}{|l|c|c|c|c|c|}
\hline Statements & VS & MS & SwS & NS & NaaS \\
\hline Amla candies preparation & $15(21.42)$ & $18(25.71)$ & $28(40.00)$ & $05(7.14)$ & $04(5.71)$ \\
\hline Jackfruit Jamoon made with seed powder & $10(14.28)$ & $25(35.71)$ & $23(32.85)$ & $10(14.28)$ & $02(2.85)$ \\
\hline Mango candies preparation & $22(31.42)$ & $28(40.00)$ & $20(28.57)$ & --- & --- \\
\hline Mango/Tomato pulp extraction & $18(25.71)$ & $38(54.28)$ & $14(20.00)$ & ---- & ---- \\
\hline Packing and marketing of value added products & $05(7.14)$ & $\mathbf{3 7 ( 5 2 . 8 5 )}$ & $18(25.71)$ & $05(7.14)$ & $05(7.14)$ \\
\hline Preparation of Tomato ketch up, chutney, pickle & $28(40.00)$ & $\mathbf{4 0}(\mathbf{5 7 . 1 4})$ & $02(2.85)$ & --- & --- \\
\hline Preparation of ragi malt & $15(21.42)$ & $20(28.57)$ & $17(24.28)$ & $08(11.42)$ & $10(14.28)$ \\
\hline
\end{tabular}

VS- Very Skilled, MS- Moderately Skilled, SwS-Somewhat Skilled, NaaS- Not at all Skilled

Table.5 Overall adoption level of value addition training programmes

\begin{tabular}{|l|c|c|}
\hline Adoption level & Frequency & Percentage \\
\hline Full adoption & 28 & 40.00 \\
\hline Partial adoption & 17 & 24.28 \\
\hline Haven't tried & 25 & 35.71 \\
\hline
\end{tabular}


Fig.1 Knowledge score of participants pre and post trainings of value addition

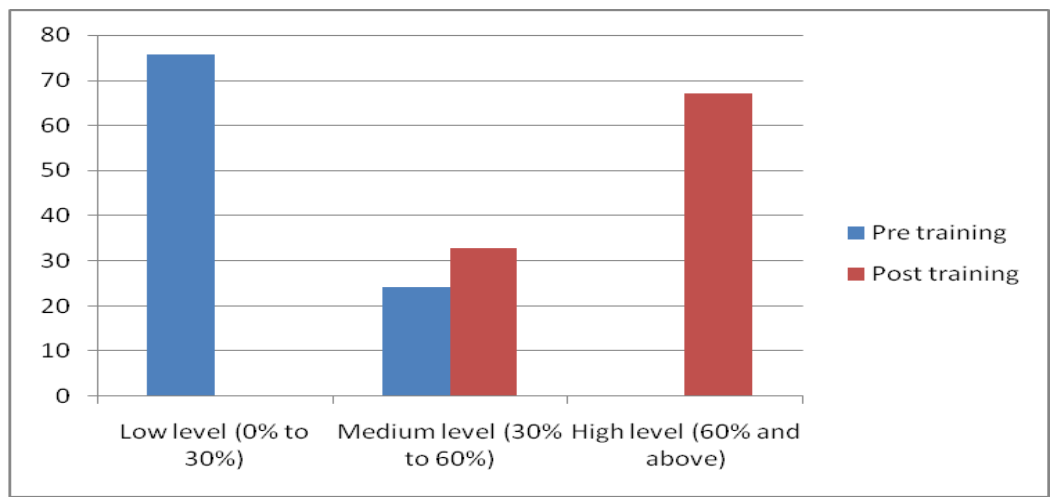

Fig.2 Overall adoption level of value addition training programmes

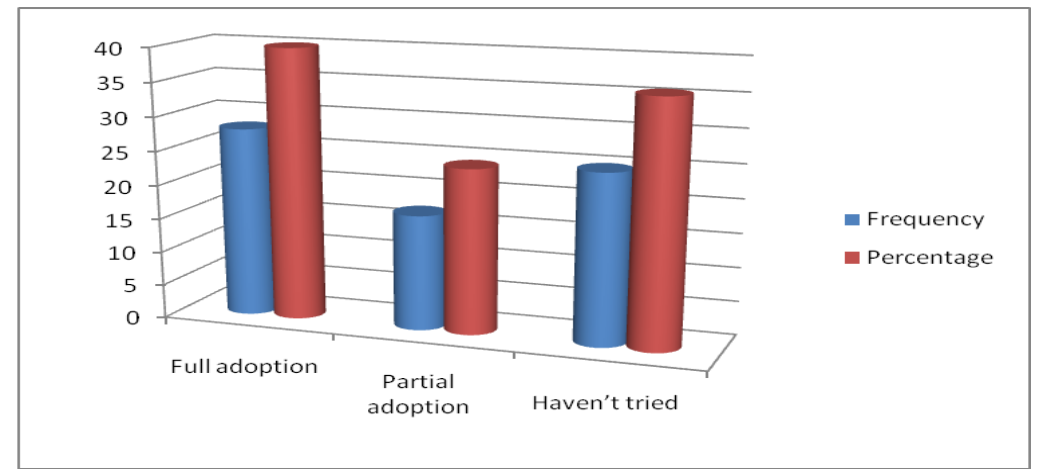

Table 4 (a) and (b) clearly states the distribution of respondent's adoption level of the perceived knowledge and skills acquired through value addition training programmes. Almost half of the participants $(57.14 \%)$ were very knowledgeable and moderately skilled on value added products of tomato like chutney, pickle, ketch up and were adopted the technology after training programme. It is very much essential in Kolar district to prevent post harvest losses. As shown in Table 4(a) about 55.71 percent of the trainees followed by 52.85 percent were moderately knowledgeable in value addition of ragi and mango. Most of the respondents expressed that they have adopted the technologies at household level. Few of them are using the value addition practices at both household and commercial level which is presented as case studies.
About forty percent of the trainees have full adoption of the above mentioned value addition practices and 35.71 percent of them have not tried once (Table 5; Fig. 1 and 2).

\section{Case studies}

Mrs. Shilpa is regularly visiting and phone conversation with Home scientist to update her knowledge on new technical aspects like masala powder preparation and other related machineries.

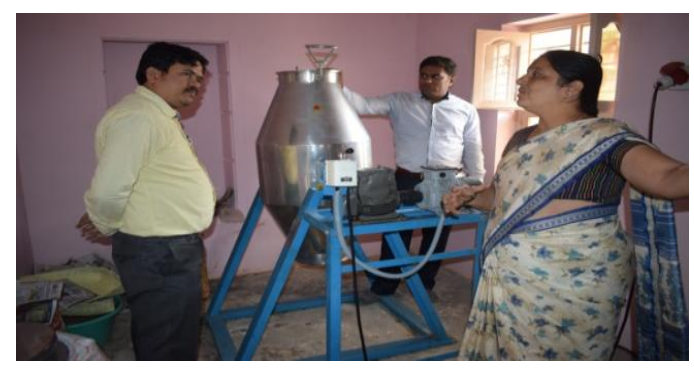


Mrs. Lilavathi 49 years, was a House wife and running provisional store of Ready To Cook (RTC) products of millets at S G Kote Village, Bangarpet.

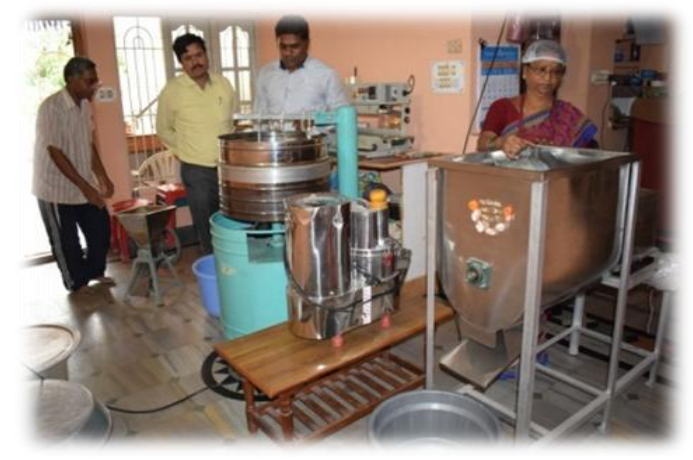

Mrs. Rathnamma is from a small village named Gundamanatta in Srinivaspur Taluk of Kolar district. She is a member of 10 SHGs pioneer in mango value added products and Diabetic mix, Upama mix, Dosa mix, Idli mix and Papads.

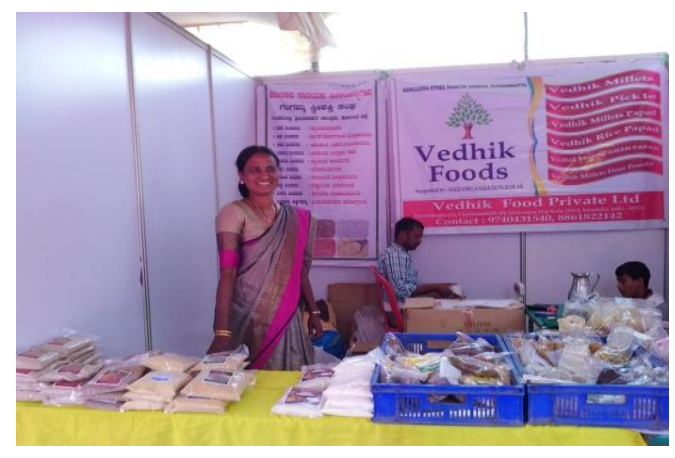

Based on the findings of the study, it can be concluded that:

Value addition training of KVK have brought a considerable positive impact on the beneficiaries in terms of perceived knowledge, skills acquired and adoption level.

To increase the level of adoption, beneficiaries needs to be provided credit with a minimum interest rate and generating market at the root level by the government.

For developing skills among the beneficiaries number of skill oriented training along with number of follow up activities should be carried out.

Therefore this study may be helpful in developing or planning future value added training programme in such a way that is conducive to farm women, SHGs.

\section{References}

Amanor-Boadu, V.: Strategic thinking for agricultural value-added businesses, The Kansas Ag Innovation Center, Department of Agricultural Economics, Kansas State University, USA (2000).

Deshpande, C.S., 2005. Contracting framing as means of value-added agriculture, Occasional paper 40, Department of Economic Analysis and Research, National Bank for Agriculture and Rural Development, Mumbai.

Eswarappa, G., 2006. Food Processing and Value Addition Technology: Means to Empower Rural Women. Paper Presented in International Conference on Social Science Perspectives in Agricultural Research and Development. IARI, New Delhi, pp: 295.

Francis, A.: Value-added agriculture: from our futures on the table, A Publication of ATTRA- National Sustainable Agriculture Information Service (2006).

Kaur, Yashpal and Sehgal, Salil: Impact of nutritional education of knowledge and practices of Rural women. Indian J. Ext. Edu., 21: 80-81 (1995).

Narayanaswamy, B.K., N. Gowda and G. N. Nagaraj, 2007. Performance of selfhelp groups of Karnataka in farm activities. Karnataka Journal of Agricultural Sciences, 20: 85-88.

Pandey et al., 2017. Impact of Vocational 
Training on Value Addition in Knowledge and Adoption of Rural Women. Int. J. Pure App. Biosci. 5 (1): 129-134.

Shekara, P.C., 2001. Private extension in India: myths, realities, apprehensions and approaches, National Institute of Agricultural Extension Management Rajendra Nagar, Hyderabad, India.

Singh, K., Peshin, R. and Saini, S.K.: Evaluation of the agricultural vocational training programmes conducted by the Krishi Vigyan Kendras (Farm Science Centres) in Indian Punjab. J. Agri. Rural Develop. Tropics and Subtropics, 111: 67- 77 (2010).

USDA: A national information resource for value added agriculture, US Department of Agriculture, Rural Business Development, Washington, DC (2010).

\section{How to cite this article:}

Jayalaxmi Pawar, A. M. Rajesh, P. Pushpa, G. S. Chikkanna, K. Tulasiram and Ambika, D. S. 2020. Impact of Value Addition Training Programmes of KVK in Kolar District, Karnataka Int.J.Curr.Microbiol.App.Sci. 9(12): 1475-1481. doi: https://doi.org/10.20546/ijcmas.2020.912.175 